\title{
Öğretmenlerin Algılarına Göre Örgütsel Adalet ve Örgütsel Sinizm Arasındaki İlişkinin İncelenmesi *
}

\section{An Analysis of the Relationship between Organizational Justice and \\ Organizational Cynicism According to the Perceptions of Teachers}

Tuncay ŞAMDAN**, Gülsün ATANUR BASKAN ****

• Geliş Tarihi: 06.11.2018 • Kabul Tarihi: 17.04.2019 • Yayın Tarihi: 06.07.2019

\begin{abstract}
$\ddot{\mathbf{O} z}$
$\mathrm{Bu}$ araştırmanın amacı öğretmenlerin algılarına göre örgütsel adalet ile örgütsel sinizm arasındaki ilişkiyi incelemektir. Bir karma yöntem araştırması olarak tasarlanmış bu araştırmanın; nicel çalışma grubunu 789, nitel çalışma grubunu 20 öğretmen oluşturmaktadır. Araştırma sonucunda, öğretmenlerin örgütsel adalete ilişkin alg1 düzeyleri ile örgütsel sinizm düzeyleri arasında negatif yönde ve yüksek düzeyde bir ilişki olduğu saptanmıştır. Öğretmenlerin cinsiyeti, yaşı, medeni durumu, eğitim durumu, branşı, görev yaptıkları okul türü örgütsel adalet algılarında anlamlı farklılaşmaya neden olurken mesleki kıdem değişkeninin anlamlı bir farka neden olmadığ 1 görülmüştür. Nitel bulgulara göre örgütsel adalet algısının düşük olduğu durumlarda; öğretmenlerin sinik davranışlar sergiledikleri fakat bu sinik tutumlarını eğitim öğretim ortamına yansıtmadıkları saptanmıştır.
\end{abstract}

Anahtar Sözcükler: Sinizm, örgütsel sinizm, adalet, örgütsel adalet

Atıf:

Şamdan, T., ve Atanur Başkan, G. (2019). Öğretmenlerin algılarına göre örgütsel adalet ve örgütsel sinizm arasındaki ilişkinin incelenmesi. Pamukkale Üniversitesi Eğitim Fakültesi Dergisi, 47, 17-40. doi: 10.9779/pauefd.479173

\footnotetext{
* Bu çalışma, Tuncay ŞAMDAN'ın Gülsün ATANUR BASKAN danışmanlığında 2019 yılında tamamladığı aynı başliklı doktora tezinden üretilmiştir.

** Okul Müdürü, Okan Koleji, ORCID: 0000-0001-9907-6731, tsamdan@gmail.com

*** Prof. Dr., İstanbul Okan Üniversitesi, Eğitim Fakültesi, ORCID: 0000-0002-3198-8870 gulsun.baskan@okan.edu.tr
} 


\begin{abstract}
The aim of this study is to examine the relationship between organizational justice and organizational cynicism according to the perceptions of teachers.789 teachers constitute the quantitative and 20 teachers constitute the qualitative sample group of this mixed method study. As a result of the research, it was determined that there was a significant and strong relationship between teachers' organizational justice perception levels and organizational cynicism levels. Again, according to the qualitative findings, when the teachers' perception of organizational justice is low, teachers showed cynic behaviors, but they did not reflect these cynical attitudes in the educational environment.
\end{abstract}

Keywords: Cynicism, organizational cynicism, justice, organizational justice

\title{
Cited:
}

Şamdan, T., \& Atanur Başkan, G. (2019). An analysis of the relationship between organizational justice and organizational cynicism according to the perceptions of teachers. Pamukkale Üniversitesi Eğitim Fakültesi Dergisi, 47, 17-40. doi: 10.9779/pauefd.479173 


\section{Giriş}

Örgütsel etkililiği, verimliliği, dinamizmi ve örgütsel bağl1lığı etkilediği için örgütsel adalet ve örgütsel sinizm konuları tüm örgütlerde olduğu gibi eğitim örgütlerinde de son y1llarda çalışılan konular olmuştur. Alanyazın incelendiğinde örgütsel adaletin; örgütsel bağlllık, örgütsel vatandaşlık, örgütsel güven kavramlarıyla ilişkili olması nedeniyle de tüm örgütlerde olduğu gibi eğitim örgütlerinde de gitgide önem kazanan bir kavram haline geldiği saptanmıştır. Küreselleşen dünya ekonomisi çalışanların uğradıklarını düşündükleri haksızlıklar, hayal kırıklıkları nedeniyle örgütsel sinizmin yıkıcı etkilerini artırırken, örgütsel adaletin de önemini artırmıştır. Örgüt, toplumun gereksinim duyduğu bir malı, hizmeti veya düşünceyi üretmek için bir araya gelen insanlardan oluşur (Başaran, 2004). Yönetim ise, belirli amaçlara ulaşmak için başta insan olmak üzere örgütteki tüm kaynakları birbiriyle uyumlu, verimli ve etkili kullanabilecek kararları alma ve uygulatma sürecidir (Gümüş̧eli, 2014). Tüm örgütlerde olduğu gibi hammaddesi ve çıktısı insan olan eğitim örgütlerinde de öğretmenlerin örgütsel adalet ve örgütsel sinizm algıları örgütsel etkililiği, yani örgütsel amaçlara ulaşmayı bu değişkenlere bağlı olarak olumlu veya olumsuz yönde etkilemektedir. Gerald'a (2002) göre iş görenler örgütsel kararlarda ve yönetsel faaliyetlerde önyargı ve haksızlık olduğunu algıladıklarında örgüte ve yönetime karşı kızgınlık, kırgınlık ve öfke gibi negatif duygular hissedip, sinik tutumlar geliştirebilmektedir.

\section{Örgütsel Adalet}

Alan yazın incelendiğinde "adalet" ve "örgütsel adalet kavramları ile ilgili pek çok tanıma rastlanmaktadır. Türk Dil Kurumu (2017) sözlügünnde "adalet” herkese kendine uygun düşeni, kendi hakkı olanı verme, doğruluk. Hak ve hukuka uygunluk, hakkı gözetme olarak tanımlanmaktadır. Örgütsel adalet ise, çalışanların kurumda ne dereceye kadar adil muamele gördüklerine ilişkin algılarını ifade eder (Greenberg, 1990). Örgütsel adalet, örgütsel çıktıların ve kazanımların (ödül, ceza, statü vb.) nasıl ve hangi yöntemlerle dağıtılacağı, dağıtım kararlarının alınması ve kişiler arası uygulamalara ilişkin örgütsel kurallar ve sosyal normlardır (Folger ve Cropanzano, 1988). Genel bir tanımla örgütsel adalet "Ödül, ceza, terfi vb. örgütsel kaynakların dağıtımıyla ilgili olarak alınan kararlar, bu kararların alınış ve uygulama biçimlerine ilişkin örgütsel kurallar, normlar ve bunların uygulanmasının adil olup olmadığına ilişkin iş görenlerde oluşan adalet algısıdır." Alanyazında örgütsel adaletin dağıtımsal adalet, işlemsel adalet ve etkileşimsel adalet olmak üzere üç boyutlu bir yapıdan oluştuğu ifade edilmektedir. Dağıtım adaleti, iş görene verilen ücret ve terfilerin adil olup olmadığıyla ilgilidir (Moorman, 1991). İşlemsel adalet bireylerin karar alma süreçlerine katılabilmeleri ve karar alma sürecinin tarafsız ve objektif kriterlere dayanıp dayanmadığına ilişkin algıyı ifade eder (Moon vd., 2008). Etkileşim adaleti ise, dağıtım adaletine ilişkin alınan kararların nasıl aktarıldığına ilişkin algıyı ifade eder (Cropanzano vd., 2001).

\section{Örgütsel Sinizm}

Sinizm, bir kişiye, guruba, ideolojiye, sosyal geleneğe ya da örgüte karşı hissedilen, hayal kırıklı̆̆ı, hüsran, güvensizlik ve olumsuz duyguları içeren özel bir tutumdur (Andersson, 1996). Örgütsel sinizm ise, örgüte karşı olumsuz duyguları, küçük düşürücü, eleştirel davranışları içeren ve örgütün bütünlükten yoksun olduğu inancına dayanan bir tutumdur (Dean\& Brandes, Dharwadkar,1998). Başka bir ifadeyle, örgütsel sinizm “ Küreselleşen yeni dünya düzeninde, 
çalışanların örgüte sağladıkları katkıların karşılığını alamadıklarını ya da uğradıklarını düşündükleri haksızlıklar veya adil olmayan uygulamalar nedeniyle; örgüte karşı hissettikleri hayal kırıklığı, kızgınlık, güvensizlik vb. duygulardan kaynaklanan olumsuz tutum ve davranışlardır." Örgütsel sinizm bilişsel, duyuşsal ve davranışsal sinizm olmak üzere üç boyutlu bir yapıdan oluşmaktadır. Bilişsel boyut, örgütün dürüstlükten yoksun olduğuna dair inançtır. Sinik kişiler, örgütsel uygulamalarda adalet, dürüstlük ve samimiyet gibi değer ve ilkelerin göz ard1 edildiğine ve etik dışı davranışların örgütsel normlara dönüştüğüne inanırlar (Dean vd., 1998). Bilişsel sinizm, bireye, guruba, bir ideolojiye, sosyal geleneğe ya da örgüte karş1 güvensizliği ifade eden inançtır (Anderson ve Bateman, 1996). Duyuşsal boyutta öfke, mahcubiyet duyma, nefret etme gibi örgüte yönelik içsel tepki içeren negatif duygular yer almaktadır (Dean, Brandes ve Dharwadkar, 1998). Davranışsal boyutun kapsamına bireylerin örgüte karşı bilişsel boyutta oluşturdukları olumsuz inanışların duyuşsal boyutta örgüte yönelik olumsuz duygulara dönüşmesinin bir sonucu olarak örgüte yönelik fiili eylem ve eğilimler girmektedir (Helvac1, 2010).

Brandes ve Das'ın (2015)" İşyerinde davranışsal sinizm” adlı çalışması da sinik davranışların, çalışanların iş performansı üzerinde önemli etkilere sahip olduğunu göstermiştir. Cropanzano vd. (2007), "Örgütsel adalet yönetimi” adlı araştırmalarında örgütsel adaletin hem kuruluşlar hem de çalışanlar için güçlü faydalar yaratma potansiyeline sahip olduğunu ortaya koymuştur. Bunlar arasında daha fazla güven ve bağlılık, daha iyi iş performansı, daha yararlı vatandaşlık davranışları ve daha az çatışma bulunmaktadır. Köybaşı vd. (2017) "Öğretmenlerin örgütsel adalet algıları ile örgütsel sinizm düzeyleri arasındaki ilişkinin incelenmesi” adlı araştırmanın bulgularına göre örgütsel sinizm ile örgütsel adalet arasında yüksek düzeyde ilişki olduğu saptanmıştır. Ürünün, hizmetin nitelikli olarak üretilebilmesi için iş görenlerin, el birliği, gönül birliği içinde dayanışma ile eş güdüm içinde çalışması etkili ve dinamik bir örgüt için zorunluluktur. $\mathrm{Bu}$ da ancak ve ancak, örgütsel adaletin sağlanabildiği örgütlerde mümkündür (Başaran, 2004).

Alan yazın incelendiğinde olumlu bir örgüt iklimi, örgüt kültürü ve etkili bir öğretme öğrenme ortamı yaratmada çok önemli iki kavram olan örgütsel adalet ve örgütsel sinizm konularının Türkiye'de özellikle ilkokul ve ortaokul düzeyinde yeterince incelenmediği görülmüş ve alan yazına katkı yapacağı düşünülerek böyle bir araştırmaya ihtiyaç duyulmuştur.

\section{Araştırma Problemi}

Araştırmanın problem cümlesi "ilkokul ve ortaokul ögrretmenlerinin algllarına göre örgütsel adalet ile örgütsel sinizm arasındaki ilişkinin incelenmesi" şeklinde belirlenmiş ve bu amaç doğrultusunda şu sorulara yanıt aranmıştır:

1. Öğretmenlerin görev yaptıkları okullara ilişkin örgütsel adalet ve örgütsel sinizm algı düzeyleri nedir?

2. Öğretmenlerin örgütsel adalet algıları ve örgütsel sinizm düzeyleri arasında anlamlı bir ilişki var mıdır?

3. Öğretmenlerin örgütsel adalete ilişkin algıları ve örgütsel sinizm düzeyleri cinsiyet, yaş, eğitim durumu, okul türü vb. demografik özelliklerine göre farklılık göstermekte midir? 
4. Öğretmenlerin “adalet ve adil olmak” kavramlarına ilişkin görüşleri nelerdir?

5. Adil olmayan örgütsel uygulamaların öğretmenlerin üzerindeki etkileri nelerdir?

\section{Yöntem}

Öğretmenlerinin algılarına göre örgütsel adalet ile örgütsel sinizm arasındaki ilişkiyi incelemek amacıyla yapılan bu araştırma bir karma yöntem araştırması (nicel ve nitel) olarak tasarlanmış olmakla birlikte temelde betimsel nitelikte, ilişkisel tarama modeli esas alınarak yapılmış bir çalışmadır.

\section{Çalışma Grubu}

$\mathrm{Bu}$ araştırmanın evrenini 2017-2018 eğitim öğretim yılında İstanbul Anadolu yakasındaki 14 ilçede bulunan resmi ve özel ilkokul ve ortaokullarda görev yapan 31.167 öğretmen, çalışma grubunu ise 789 öğretmen oluşturmaktadır. Temelde nicel bir araştırma olan bu karma yöntem araştırmasının nitel çalışma grubunu ise 10'u resmi okul, 10'u da özel okuldan olmak üzere; 13 kadın, 7 erkek 20 öğretmen oluşturmaktadır. Örneklem büyüklügünün, belirlenen istatistiksel kurallar çerçevesinde, ana evrenden \% 99 güvenirlik sınırları içinde \% 5'lik bir hata payı dikkate alınarak 'oranlı eleman örnekleme' yöntemine göre en az 652 olması gerektiği hesaplanmış ve detayları tablo 1'de verilen 789 kullanılabilir anket ve ölçek dönüşü olmuştur.

Tablo 1. Dönen Anket-Ölçek Sayısı ve Evrene Göre Dönüş Oranları (N=789)

\begin{tabular}{|c|c|c|c|c|c|c|c|c|c|c|}
\hline \multirow{3}{*}{ İlçe } & \multicolumn{4}{|c|}{ İlkokul } & \multicolumn{4}{|c|}{ Ortaokul } & \multirow{2}{*}{\multicolumn{2}{|c|}{ Toplam }} \\
\hline & \multicolumn{2}{|c|}{ Resmi } & \multicolumn{2}{|c|}{ Özel } & \multicolumn{2}{|c|}{ Resmi } & \multicolumn{2}{|c|}{ Özel } & & \\
\hline & $\mathrm{f}$ & $\%$ & $f$ & $\%$ & $\mathrm{f}$ & $\%$ & $\mathrm{f}$ & $\%$ & $\mathrm{f}$ & $\%$ \\
\hline Adalar & 5 & 15,2 & 0 & 0,0 & 0 & 0,0 & 0 & 0,0 & 5 & 7,8 \\
\hline Ataşehir & 18 & 1,9 & 11 & 2,4 & 26 & 2,7 & 8 & 1,6 & 63 & 2,2 \\
\hline Beykoz & 8 & 1,3 & 4 & 4,8 & 23 & 3,7 & 7 & 4,8 & 42 & 2,8 \\
\hline Çekmeköy & 15 & 2,6 & 4 & 1,1 & 21 & 4,1 & 13 & 3,1 & 53 & 2,8 \\
\hline Kadıköy & 24 & 3,1 & 32 & 9,4 & 31 & 3,8 & 5 & 1,2 & 92 & 3,9 \\
\hline Kartal & 6 & 0,6 & 15 & 6,1 & 27 & 3,0 & 11 & 3,2 & 59 & 2,3 \\
\hline Maltepe & 46 & 4,7 & 20 & 9,0 & 2 & 0,2 & 21 & 6,1 & 89 & 3,6 \\
\hline Pendik & 20 & 1,0 & 2 & 1,2 & 29 & 1,7 & 13 & 5,4 & 64 & 1,6 \\
\hline Sancaktepe & 11 & 1,1 & 12 & 4,7 & 19 & 2,7 & 9 & 3,6 & 51 & 2,3 \\
\hline Sultanbeyli & 4 & 0,4 & 0 & 0,0 & 25 & 4,1 & 0 & 0,0 & 29 & 1,8 \\
\hline Şile & 3 & 3,7 & 0 & 0,0 & 4 & 4,2 & 0 & 0,0 & 7 & 3,9 \\
\hline Tuzla & 46 & 6,3 & 8 & 2,9 & 21 & 3,3 & 8 & 2,6 & 83 & 4,3 \\
\hline Ümraniye & 55 & 3,5 & 6 & 1,2 & 23 & 1,7 & 5 & 0,9 & 89 & 2,2 \\
\hline Üsküdar & 10 & 0,9 & 16 & 2,3 & 13 & 1,2 & 24 & 3,2 & 63 & 1,7 \\
\hline Genel & 271 & 2,2 & 130 & 3,6 & 264 & 2,4 & 124 & 2,9 & 789 & 2,5 \\
\hline
\end{tabular}

Örneklemi oluşturan öğretmenlerin demografik/kişisel özellikleri aşağıda, Tablo 2.'de özetlenmiştir. 
Tablo 2. Öğretmenlerin Demografik Özelliklerine İlişkin Frekans ve Yüzde Dağılımı $(\mathbf{N}=\mathbf{7 8 9})$

\begin{tabular}{|c|c|c|c|}
\hline Değişken & Grup & $\mathrm{f}$ & $\%$ \\
\hline \multirow{2}{*}{ Cinsiyet } & Kadın & 583 & 73,9 \\
\hline & Erkek & 206 & 26,1 \\
\hline \multirow{4}{*}{ Yaş } & 30 ve alt & 142 & 18,0 \\
\hline & $31-40$ & 360 & 45,6 \\
\hline & $41-50$ & 209 & 26,5 \\
\hline & 51 ve üstü & 78 & 9,9 \\
\hline \multirow[t]{2}{*}{ Medeni durum } & Evli & 587 & 74,4 \\
\hline & Bekâr & 202 & 25,6 \\
\hline \multirow[t]{3}{*}{ Eğitim düzeyi } & Ön Lisans & 26 & 3,3 \\
\hline & Lisans & 574 & 72,8 \\
\hline & YL/Doktora & 189 & 24,0 \\
\hline \multirow[t]{2}{*}{ Branş } & Sınıf öğretmeni & 319 & 40,4 \\
\hline & Branş öğretmeni & 470 & 59,6 \\
\hline \multirow{2}{*}{$\begin{array}{l}\text { Görev yapılan } \\
\text { kademe }\end{array}$} & İlkokul & 401 & 50,8 \\
\hline & Ortaokul & 388 & 49,2 \\
\hline \multirow{2}{*}{$\begin{array}{l}\text { Görev yapılan } \\
\text { Okul türü }\end{array}$} & Resmi okul & 535 & 67,8 \\
\hline & Özel okul & 254 & 32,2 \\
\hline \multirow{5}{*}{ Mesleki kıdem } & $1-5 \mathrm{y} 1 \mathrm{l}$ & 109 & 13,8 \\
\hline & $6-10 y_{1} 1$ & 159 & 20,2 \\
\hline & $11-15 \mathrm{y} 1 \mathrm{l}$ & 189 & 24,0 \\
\hline & $16-20$ y1l & 153 & 19,4 \\
\hline & 21 yıl ve üstü & 179 & 22,7 \\
\hline \multirow{4}{*}{ Okuldaki çalışma süresi } & $1-3$ y1l & 353 & 44,7 \\
\hline & $4-6$ y1l & 241 & 30,5 \\
\hline & $7-9$ y1l & 79 & 10,0 \\
\hline & 10 yıl ve üstü & 116 & 14,7 \\
\hline
\end{tabular}


Tablo 3. Yüzyüze Görüşme Yapılan Öğretmenlerin Demografik Özelliklerine İlişkin Frekans ve Yüzde Dağılımı (N=20)

\begin{tabular}{llcc}
\hline Değişken & Grup & $\mathrm{f}$ & $\%$ \\
\hline \multirow{2}{*}{ Cinsiyet } & Kadın & 13 & 65 \\
& Erkek & 7 & 35 \\
& & & \\
Branş & Sinıf öğretmeni & 8 & 40 \\
& Branşögretmeni & 12 & 60 \\
& & & \\
Görev yapılan & & & \\
Okul türü & Resmi okul & 10 & 50 \\
& Özel okul & 10 & 50 \\
\hline
\end{tabular}

\section{Veri Toplama Araçları}

\section{Kişisel Bilgi Formu}

Araştırmacı tarafından ilkokul ve ortaokul öğretmenlerinin demografik özelliklerini (cinsiyeti, yaş1, medeni durumu, eğitim düzeyi, branş1, vb.) belirlemek üzere 12 soruluk Kişisel Bilgi Formu kullanılmıştır.

\section{Örgütsel Adalet Ölçeği}

Öğretmenlerin, örgütsel adalete ilişkin algılarını ölçmek üzere Niehoff ve Moorman (1993) tarafından geliştirilen ve Polat (2007) tarafından Türkçeye uyarlanan 19 madde ve üç faktörden oluşan 5'li Likert tipi “Örgütsel Adalet Ölçeği” kullanılmıştır. Örgütsel Adalet Ölçeği ve alt boyutlarında yer alan maddelerin güvenirlilik analizleri için Alpha modeli ile maddeler arası korelasyona bağlı uyum değerleri hesaplanmıştır. Cronbach Alfa $(\alpha)$ katsayılarının değerlendirilmesinde şu sınırlar dikkate alınmıştır: $0.00 \leq \alpha<0.40$ ise ölçek/alt boyut güvenilir değildir, $0.40 \leq \alpha<0.60$ ise alt boyutun güvenilirliği düşük, $0.60 \leq \alpha<0.80$ ise alt boyut oldukça güvenilir ve $0.80 \leq \alpha<1.00$ ise ölçek/alt boyut yüksek derecede güvenilirdir (Karagöz, 2016). Dağıtımsal Adalet için güvenirlik katsayısı (Cronbach's Alpha) $\alpha=0,924$; İşlemsel için 0,961 ve Etkileşimsel için 0,949 olarak hesap edilmiştir. Dağıtımsal Adalet alt boyutuna ait maddetoplam korelasyon katsayıları 0,708 ile 0,837; İşlemsel Adalet alt boyutunun 0,815 ile 0,857 ve Etkileşimsel Adalet alt boyutunun 0,864 ile 0,894 arasında olduğu bulunmuş ve maddeler ile boyutlar arasında yeterli düzeyde ilişki olduğu görülmüştür. Örgütsel Adalet Ölçeğinin 19 maddesi birlikte analize dahil edildiğinde genel güvenirlik katsayısının 0,977 olduğu bulunmuştur. 
Tablo 4. Örgütsel Adalet Ölçeğine İlişkin Doğrulayıcı Faktör Analizi

\begin{tabular}{lcccccccccc}
\hline & \multicolumn{10}{c}{ Model Uyum İstatistikleri } \\
\cline { 2 - 9 } & $X^{2}$ & $s d$ & $X^{2} / s d$ & GFI & AGFI & RMSEA & RMR & NFI & CFI \\
\hline Örgütsel Adalet Ö. & 433,59 & 149 & 2,91 & 0,930 & 0,892 & 0,062 & 0,049 & 0,917 & 0,936
\end{tabular}

RMSEA'nın 0,050'den küçük olmas1 'mükemmel', 0,080'den küçük olmas1 'iyi' ve 0,10'dan küçük olması ise 'zayıf' uyuma işaret etmektedir (Jöreskog ve Sörbom,1979). Buna göre; Örgütsel Adalet Ölçeği modelinin uyumu 'iyi' düzeydedir ve diğer uyum indeksi değerleri de test edilen modelin araştırma örnekleminde geçerli ve güvenilir olduğunu göstermektedir.

Örgütsel Sinizm Ölçĕgi

Öğretmenlerin, örgütsel sinizm düzeylerini ölçmek üzere Brandes, Dharwadkar ve Dean (1999) tarafından geliştirilen ve Kalağan (2009) tarafından Türkçeye uyarlanan, toplam 13 madde ve üç faktörden oluşan 5'li Likert tipi “Örgütsel Sinizm Ölçeği” kullanılmıştır. Bilişsel Sinizm için güvenirlik katsayısı (Cronbach’s Alpha) $\alpha=0,921$; Duyuşsal Sinizm için 0,962 ve Davranışsal Sinizm için 0,871 olarak hesaplanmıştır. Ölçeğin bilişsel alt boyutuna ait madde-toplam korelasyon katsayıları 0,777 ile 0,838; duyuşsal alt boyutun 0,873 ile 0,932 ve davranışsal boyut için 0,673 ile 0,787 arasında bulunarak yeterli düzeyde ilişki olduğu sonucuna varılmıştır. Örgütsel Sinizm Ölçeğinin tüm maddeleri birlikte analize dahil edildiğinde ise genel güvenirlik katsayısı 0,945 bulunmuştur.

Tablo 5. Örgütsel Sinizm Ölçeğine İlişkin Doğrulayıcı Faktör Analizi

\begin{tabular}{lcccccccccc}
\hline & \multicolumn{10}{c}{ Model Uyum İstatistikleri } \\
\cline { 2 - 8 } & $X^{2}$ & $s d$ & $X^{2} / s d$ & GFI & AGFI & RMSEA & RMR & NFI & CFI \\
\hline Örgütsel Adalet Ö. & 169,26 & 62 & 2,73 & 0,928 & 0,899 & 0,048 & 0,036 & 0,911 & 0,913
\end{tabular}

RMSEA'nın 0,050'den küçük olması 'mükemmel', 0,080'den küçük olması 'iyi' ve 0,10'dan küçük olması ise 'zayıf' uyuma işaret etmektedir (Jöreskog ve Sörbom,1979). Buna göre; Örgütsel Sinizm Ölçeği modelinin uyumu 'mükemmel' düzeydedir ve diğer uyum indeksi değerleri de test edilen modelin araştırma örnekleminde geçerli ve güvenilir olduğunu göstermektedir.

\section{Yüz Yüze Görüşme Formu}

Araştırmanın nitel kısmı için araştırmacı tarafından geliştirilen yüz yüze görüşme formu kullanılmıştır. İlgili alan yazın taranarak ve uzman görüşleri alınarak geliştirilen görüşme formu ile ön uygulama yapılmış, eksiklikler giderilerek görüşme formuna son şekli verilmiş ve asıl uygulama aşamasına geçilmiştir. Veri analizleri sonucunda belirlenen temalara göre soruların dağılımı şu şekildedir: Tema 1- Adalet ve adil olmak : "Adalet" "adil olmak" kavramı size ne ifade ediyor ( Adil olan bir kişi hangi özellikleri taşır)?, Çalıştığınız kurumda ödül, terfi, görev ve kaynak dağılımları sizce nasıl yapılıyor (Objektif kriterler var mı, adil ve eşit mi )?, Tema 2Adil olmayan uygulamaların öğretmenler üzerindeki etkileri : Görev yaptığınız kurumda adil 
uygulamalar olmadığını algıladığınız zamanlar ne tür tepkiler veriyorsunuz? Bu durum sizi nasıl etkiliyor?, Okulunuza karşı olumsuz duygular hissettiğinizde; Bunun okula ve eğitim ortamına yansımaları ne şekilde oluyor, kendinize olan yansımaları ne şekilde oluyor, yöneticilerinize yansımaları nasıl oluyor?, Tema 3- Kararlara katılım: Okulun işleyişi hakkında bilgi sahibi misiniz (Karar süreci nasıl işliyor, kararlar size nasıl bildiriliyor)?, Tema 4- İletişim ve etkileşim: Okulunuzda iş görenler arasındaki iletişim ve etkileşim nasıldır (Okul yöneticileriöğretmen, öğretmen-öğretmen)?

\section{Verilerin Analizi}

Öğretmenlerden, Kişisel Bilgi Formu, Örgütsel Adalet Ölçeği ve Örgütsel Sinizm Ölçeği ile toplanan verilerin tümü SPSS 23.0 for Windows programına aktarılmış ve istatistiksel analizler yapılmıştır. Örgütsel Adalet Ölçeği ve Örgütsel Sinizm Ölçeklerinin bu çalışma için uygunluğunu test etmek üzere (doğrulayıcı faktör analizleri için-DFA) ise AMOS 23 programı kullanılmıştır. Toplanan veriler ile herhangi bir istatistiksel analiz yapılmadan önce, bu verilerin anket formu ile belirlenen sınırlar içinde olup olmadığı, hatalar ve ciddi oranda eksiklikler barındırıp barındırmadığı kontrol edilmiş daha sonra ise parametrik ve non-parametrik analizlerden hangilerinin uygulanacağına kara vermek üzere normallik dağılımları incelenmiş, sonrasında aşağıdaki analizler yapılmıştır;

Öğretmenlerin; Örgütsel adalet alg1S1 ve örgütsel sinizm düzeylerini araştırmak üzere, ölçek ve alt boyutlarına ilişkin puanların ortalaması $(\bar{X})$ ve standart sapma (ss) değerleri, örgütsel adalet algıları ile örgütsel sinizm düzeyleri arasındaki ilişkileri araştırmak üzere Pearson momentler çarpımı korelasyonu katsayıları hesaplanmış ve örgütsel adalet algılarının örgütsel sinizm düzeyleri üzerindeki etkisini araştırmak üzere doğrusal regresyon analizi uygulanmıştır.

Öğretmenlerin, cinsiyete, görev yapılan okul kademesine ve görev yapılan okul türüne bağlı olarak, örgütsel adalet algıları ve örgütsel sinizm düzeyleri arasında anlamlı fark olup olmadığını araştırmak üzere bağımız/ilişkisiz gruplar t-testi uygulanmıştır.

Öğretmenlerin, yaş, medeni durum, mesleki kıdem ve şu anki okulda çalışma süresine bağlı olarak, örgütsel adalet algıları ve örgütsel sinizm düzeyleri arasında anlamlı fark olup olmadığını araştırmak üzere tek-yönlü varyans analizi (one-way ANOVA) uygulanmıştır. Anlamlı fark bulunduğu durumda ise hangi gruplar arasında anlamlı fark olduğunu araştırmak üzere post-hoc Scheffe testi yapılmıştır.

Öğretmenlerin, eğitim durumu ve branşa bağlı olarak, örgütsel adalet algıları ve örgütsel sinizm düzeyleri arasında anlamlı fark olup olmadığını araştırmak üzere (normallik varsayımı sağlanamadığında) Kruskal-Wallis testi uygulanmıştır. Anlamlı fark bulunduğu durumda ise hangi gruplar arasında anlamlı fark olduğunu araştırmak üzere post-hoc Mann-Whitney U testi yapılmışıtır.

Yapılan tüm istatistiksel hesaplamalarda temel anlamlılık düzeyi 0,05 olarak kabul edilmiştir.

Araştırmanın nitel kısmını oluşturan görüşme formu 10'u resmi okul, 10'u da özel okuldan olmak üzere toplam 20 öğretmene (13 kadın, 7 erkek) uygulanmıştır. Her bir görüşme yaklaşık 20-25 dakika sürmüştür. Yüz yüze yapılan bu görüşmeler görüşmecilerin izni alınarak 
ses kayıt cihazı ile kayıt edilmiştir. Görüşme verilerinin analizinde şu aşamalar izlenmiştir. Görüşme verilerinin yazıya geçirilmesi, verilerinin düzenlenmesi, anlamlı veri birimlerinin saptanmasi, taslak temaların belirlenmesi, taslak tema ve kodlara göre verinin düzenlenmesi, temaların kontrol edilmesi ve kesinleştirilmesi, temaların araştırma soruları altında organize edilmesi, alıntılara yer verilmesi, açıklanması, yorumlanması ve nicel araştırma bulgularıyla birlikte değerlendirilmesi.

\section{Bulgular}

Tablo 6. Öğretmenlerin Örgütsel Adalet Algı Düzeylerine İlişkin Betimsel İstatistikler $(\mathrm{N}=789)$

\begin{tabular}{lccc}
\hline Boyut/Ölçek & $\bar{X}$ & ss & Düzey \\
\hline Dağıtımsal Adalet & 3,70 & 0,99 & Yüksek \\
İşlemsel Adalet & 3,75 & 1,02 & Yüksek \\
Etkileşimsel Adalet & 3,56 & 1,11 & Yüksek \\
& & & \\
Örgütsel Adalet & 3,67 & 0,99 & Yüksek \\
\hline
\end{tabular}

Tablo 6'ya göre araştırmaya katılan öğretmenlerin hem genel örgütsel adalet algılar1 hem de alt boyutlara ilişkin adalet algı düzeyleri yüksektir. Boyutlar karşılaştırıldığında, öğretmenlerin işlemsel adalet ( $\bar{X}_{\text {işlemsel Adalet }}=3,75 \pm 1,02$; 'Yüksek' düzeyde) algısının en yüksek olduğu, bunu sırasıyla dağıtımsal adalet ( $\bar{X}_{\text {Dağıtımsal Adalet }}=3,70 \pm 0,99$; 'Yüksek' düzeyde) ve daha sonra etkileşimsel adaletin ( $\bar{X}_{\text {Etkileşimsel Adalet }}=3,56 \pm 1,11$; 'Yüksek' düzeyde) takip ettiği görülmektedir. Öğretmenlerin genel örgütsel adalet algı düzeylerinin de yüksek olduğu görülmektedir ( $\bar{X}_{\text {Örgütsel Adalet }}=3,67 \pm 0,99$; 'Yüksek' düzeyde).

Tablo 7. Öğretmenlerin Örgütsel Sinizm Düzeylerine İlişkin Betimsel İstatistikler $(\mathrm{N}=789)$

\begin{tabular}{lccc}
\hline Boyut/Ölçek & $\bar{X}$ & ss & Düzey \\
\hline Bilişsel B. & 2,26 & 1,01 & Düşük \\
Duyuşsal B. & 1,79 & 1,06 & Çok Düşük \\
Davranışsal B. & 2,35 & 1,03 & Düşük \\
& & & \\
Örgütsel Sinizm & 2,13 & 0,90 & Düşük \\
\hline
\end{tabular}

Tablo 7'de görüldüğü üzere araştırmaya katılan öğretmenlerin hem genel hem de alt boyutlara ilişkin sinizm düzeyleri düşüktür. Öğretmenlerin bilişsel ( $\bar{X}_{\text {Bilişsel B. }}=2,26 \pm 1,01$; 'Düşük' düzeyde) ve davranışsal ( $\bar{X}_{\text {Davranışal в. }}=2,35 \pm 1,03$; 'Düşük' düzeyde) boyutlarının

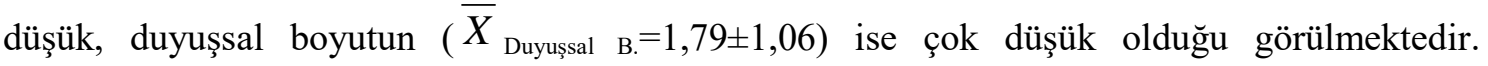
Öğretmenlerin genel örgütsel sinizm düzeylerinin de düşük olduğu görülmektedir ( $\bar{X}_{\text {Örgütsel }}$ Sinizm $=2,13 \pm 0,90$; 'Düşük' düzeyde). 
Öğretmenlerin Algılarına Göre Örgütsel Adalet ve Örgütsel Sinizm Arasındaki İlişkinin İncelenmesi 27

Tablo 8. Öğretmenlerin Örgütsel Adalet Algı Düzeyleri ile Örgütsel Sinizm Düzeyleri arasındaki İlişkilere Yönelik Bulgular $(\mathrm{N}=789)$

\begin{tabular}{|c|c|c|c|c|c|}
\hline Puan & & Bilişsel & Duyuşsal & Davranışsal & $\begin{array}{l}\text { Örgütsel Sinizm } \\
\text { (Genel) }\end{array}$ \\
\hline Dağıtımsal Adalet & $\begin{array}{l}\mathrm{r} \\
\mathrm{p}\end{array}$ & $\begin{array}{c}-, 642 * * * \\
0,000\end{array}$ & $\begin{array}{c}-, 615^{* * *} \\
0,000\end{array}$ & $\begin{array}{c}-, 555 * * * \\
0,000\end{array}$ & $\begin{array}{c}-, 690 * * * \\
0,000\end{array}$ \\
\hline İşlemsel Adalet & $\begin{array}{l}\mathrm{r} \\
\mathrm{p}\end{array}$ & $\begin{array}{c}-, 662 * * * \\
0,000\end{array}$ & $\begin{array}{c}-, 614 * * * \\
0,000\end{array}$ & $\begin{array}{c}-, 547 * * * \\
0,000\end{array}$ & $\begin{array}{c}-, 694 * * * \\
0,000\end{array}$ \\
\hline Etkileşimsel Adalet & $\begin{array}{l}\mathrm{r} \\
\mathrm{p}\end{array}$ & $\begin{array}{c}-, 629 * * * \\
0,000\end{array}$ & $\begin{array}{c}-, 562 * * * \\
0,000\end{array}$ & $\begin{array}{c}-, 531 * * * \\
0,000\end{array}$ & $\begin{array}{c}-, 655^{* * * *} \\
0,000\end{array}$ \\
\hline Örgütsel Adalet (Genel) & $\begin{array}{l}\mathrm{r} \\
\mathrm{p}\end{array}$ & $\begin{array}{c}-, 677 * * * \\
0,000\end{array}$ & $\begin{array}{c}-, 627 * * * \\
0,000\end{array}$ & $\begin{array}{c}-, 572 * * * \\
0,000\end{array}$ & $\begin{array}{c}-, 714 * * * \\
0,000\end{array}$ \\
\hline
\end{tabular}

$* * * p<.001$

Tablo 8.'de araştırmaya katılan öğretmenlerin örgütsel adalet alg1 düzeyleri ile örgütsel sinizm düzeyleri arasındaki ilişkileri incelemek üzere yapılan Pearson momentler çarpımı korelasyonuna ait katsayılar verilmiştir. Tablodan görüldügü üzere, öğretmenlerin iki ölçek ve tüm alt boyut puanları arasında negatif yönlü, $\mathrm{p}<.001$ düzeyinde anlamlı ilişkiler olduğu tespit edilmiştir. Öğretmenlerin, örgütsel adalete ilişkin algı düzeyleri ile bilişsel boyut ( $\mathrm{r}$ Örgütsel Adalet*Bilissel B. $=-, 677 ; \mathrm{p}<.001$ ), duyuşsal boyut ( $\mathrm{r}$ Örgütsel Adalet*Duyusssal B. $=-, 627 ; \mathrm{p}<.001$ ) ve davranışsal boyut ( $\mathrm{r}$ Örgütsel Adalet*Davranıssal B. $=-, 572 ; \mathrm{p}<.001)$ arasında negatif düzeyde ve güçlü derecede, genel örgütsel sinizm ( $\mathrm{r}$ Örgütsel Adalet*örgütsel Sinizm=-,714; $\mathrm{p}<.001$ ) arasında ise negatif yönde ve yüksek düzeyde anlamlı ilişki vardır.

Tablo 9. Öğretmenlerin Örgütsel Adalet Algı Düzeylerinin Cinsiyete Göre Karşılaştırılmasına Yönelik t-testi (N=789)

\begin{tabular}{|c|c|c|c|c|c|c|c|}
\hline \multirow{2}{*}{ Puan } & \multirow{2}{*}{ Cinsiyet } & \multicolumn{3}{|c|}{ Betimsel İst. } & \multicolumn{3}{|c|}{ t-test } \\
\hline & & $\mathrm{n}$ & $\bar{X}$ & ss & $\mathrm{t}$ & sd & $\mathrm{p}$ \\
\hline \multirow[t]{2}{*}{ Dağıtımsal Adalet } & Kadın & 583 & 3,58 & 0,99 & 5,77 & 787 & $0,000 * * *$ \\
\hline & Erkek & 206 & 4,03 & 0,90 & & & \\
\hline \multirow[t]{2}{*}{ İşlemsel Adalet } & Kadın & 583 & 3,65 & 1,03 & 4,55 & 787 & $0,000 * * *$ \\
\hline & Erkek & 206 & 4,02 & 0,96 & & & \\
\hline \multirow[t]{2}{*}{ Etkileşimsel Adalet } & Kadın & 583 & 3,45 & 1,12 & 4,75 & 787 & $0,000 * * *$ \\
\hline & Erkek & 206 & 3,87 & 1,03 & & & \\
\hline \multirow[t]{2}{*}{ Örgütsel Adalet } & Kadın & 583 & 3,56 & 0,99 & 5,27 & 787 & $0,000 * * *$ \\
\hline & Erkek & 206 & 3,97 & 0,92 & & & \\
\hline
\end{tabular}

$* * * p<.001$

Katılımcıların cinsiyeti değişkenine göre örgütsel adalet algı düzeylerinde anlamlı bir farklılaşma olup olmadığını araştırmak üzere yapılan bağımsız/ilişkisiz gruplar t-testine göre "cinsiyet" değişkeninin hem genel hem de tüm alt boyutlarda (dağıtımsal, işlemsel ve etkileşimsel adalet) anlamlı bir farklılaşmaya neden olduğu ve bu farkın erkek öğretmenler lehine olduğu görülmüş ve test sonuçları Tablo 9'da verilmiştir. 
Tablo 10. Öğretmenlerin Örgütsel Adalet Algı Düzeylerinin Yaşa Göre Karşılaştırılmasına Yönelik ANOVA testi (N=789)

\begin{tabular}{|c|c|c|c|c|c|c|c|}
\hline \multirow{2}{*}{ Puan } & \multirow{2}{*}{ Yaş } & \multicolumn{3}{|c|}{ Betimsel İst. } & \multicolumn{2}{|c|}{ ANOVA } & \multirow{2}{*}{ Scheffe } \\
\hline & & $\mathrm{n}$ & $\bar{X}$ & ss & $\mathrm{F}$ & Sig. & \\
\hline \multirow[t]{4}{*}{ Dağıtımsal Adalet } & 30 ve alt1 (1) & 142 & 3,58 & 1,08 & 3,19 & $0,041^{*}$ & 1 ile 3,4 \\
\hline & $31-40(2)$ & 360 & 3,65 & 0,97 & & & \\
\hline & $41-50(3)$ & 209 & 3,82 & 0,97 & & & \\
\hline & 51 ve üstü (4) & 78 & 3,79 & 0,90 & & & \\
\hline \multirow[t]{4}{*}{ İşlemsel Adalet } & 30 ve altı (1) & 142 & 3,69 & 1,09 & 0,68 & 0,567 & - \\
\hline & $31-40(2)$ & 360 & 3,72 & 0,99 & & & \\
\hline & $41-50(3)$ & 209 & 3,80 & 1,04 & & & \\
\hline & 51 ve üstü (4) & 78 & 3,85 & 1,03 & & & \\
\hline \multirow[t]{4}{*}{ Etkileşimsel Adalet } & 30 ve altı (1) & 142 & 3,54 & 1,18 & 0,52 & 0,668 & - \\
\hline & $31-40(2)$ & 360 & 3,52 & 1,08 & & & \\
\hline & $41-50(3)$ & 209 & 3,58 & 1,14 & & & \\
\hline & 51 ve üstü (4) & 78 & 3,69 & 1,06 & & & \\
\hline \multirow[t]{4}{*}{ Örgütsel Adalet } & 30 ve alt1 (1) & 142 & 3,61 & 1,05 & 0,90 & 0,442 & - \\
\hline & $31-40(2)$ & 360 & 3,63 & 0,96 & & & \\
\hline & $41-50(3)$ & 209 & 3,73 & 1,00 & & & \\
\hline & 51 ve üstü (4) & 78 & 3,77 & 0,96 & & & \\
\hline
\end{tabular}

${ }^{*} p<.05$

Yapılan tek yönlü varyans analizine (one-way ANOVA) göre öğretmenlerin yaşı sadece dağıtımsal adalet boyutunda anlamlı bir farklılaşmaya neden olduğu görülmüştür (Tablo 10). ANOVA sonrası yapılan post-hoc Scheffe testine göre; 30 ve altı yaş grubundaki ögretmenlerin

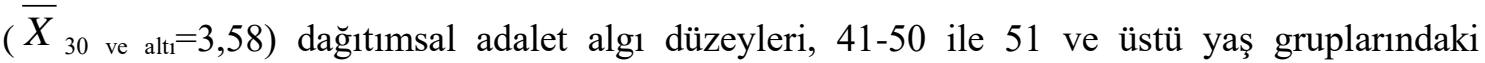

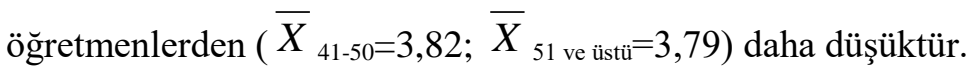

Tablo 11. Öğretmenlerin Örgütsel Adalet Algı Düzeylerinin Eğitim Duruma Göre Karşılaștırılmasına Yönelik Kruskal-Wallis testi (N=789)

\begin{tabular}{|c|c|c|c|c|c|c|c|}
\hline \multirow{2}{*}{ Puan } & \multirow{2}{*}{ Eğitim düzeyi } & \multicolumn{2}{|c|}{ Betimsel İst. } & \multicolumn{3}{|c|}{ Kruskal-Wallis } & \multirow{2}{*}{$\mathrm{M}-\mathrm{W}$} \\
\hline & & $\mathrm{n}$ & Sira Ort. & $\mathrm{X}^{2}$ & $\mathrm{sd}$ & $\mathrm{p}$ & \\
\hline Dağıtımsal & Ön Lisans (1) & 26 & 400,04 & 11,48 & 2 & $0,003 * *$ & 3 ile 1,2 \\
\hline \multirow[t]{2}{*}{ Adalet } & Lisans (2) & 574 & 410,82 & & & & \\
\hline & YL/Doktora (3) & 189 & 346,27 & & & & \\
\hline \multirow[t]{3}{*}{ İşlemsel Adalet } & Ön Lisans (1) & 26 & 423,00 & 14,28 & 2 & $0,001 * *$ & 3 ile 1,2 \\
\hline & Lisans (2) & 574 & 411,64 & & & & \\
\hline & YL/Doktora (3) & 189 & 340,61 & & & & \\
\hline Etkileşimsel & Ön Lisans (1) & 26 & 432,29 & 15,16 & 2 & $0,001 * *$ & 3 ile 1,2 \\
\hline \multirow[t]{2}{*}{ Adalet } & Lisans (2) & 574 & 411,63 & & & & \\
\hline & YL/Doktora (3) & 189 & 339,36 & & & & \\
\hline \multirow[t]{3}{*}{ Örgütsel Adalet } & Ön Lisans (1) & 26 & 421,94 & 15,52 & 2 & $0,000 * * *$ & 3 ile 1,2 \\
\hline & Lisans (2) & 574 & 412,50 & & & & \\
\hline & YL/Doktora (3) & 189 & 338,15 & & & & \\
\hline
\end{tabular}


Yapılan non-parametrik Kruskal-Wallis testine göre öğretmenlerin eğitim durumu, ölçeğin tüm alt boyutları ve geneli bakımından anlamlı bir farklılaşmaya neden olduğu görülmüştür. Yüksek lisans/doktora yapan öğretmenlerin dağıtımsal, işlemsel, etkileşimsel ve genel örgütsel adalet algı düzeyleri diğer öğretmenlerden daha düşüktür (Tablo 11).

Tablo 12. Öğretmenlerin Örgütsel Adalet Algı Düzeylerinin Görev Yaptıkları Okul Türüne Göre Karşılaştırılmasına Yönelik t- testi (N=789)

\begin{tabular}{|c|c|c|c|c|c|c|c|}
\hline \multirow{2}{*}{ Puan } & \multirow{2}{*}{ Okul türü } & \multicolumn{3}{|c|}{ Betimsel İst. } & \multicolumn{3}{|c|}{ t-test } \\
\hline & & $\mathrm{n}$ & $\bar{X}$ & ss & $\mathrm{t}$ & $\mathrm{sd}$ & $\mathrm{p}$ \\
\hline \multirow[t]{2}{*}{ Dağıtımsal Adalet } & Resmi okul & 535 & 3,74 & 0,96 & \multirow[t]{2}{*}{1,61} & \multirow[t]{2}{*}{787} & \multirow[t]{2}{*}{0,108} \\
\hline & Özel okul & 254 & 3,62 & 1,03 & & & \\
\hline \multirow[t]{2}{*}{ İşlemsel Adalet } & Resmi okul & 535 & 3,78 & 1,02 & \multirow[t]{2}{*}{1,25} & \multirow[t]{2}{*}{787} & \multirow[t]{2}{*}{0,211} \\
\hline & Özel okul & 254 & 3,68 & 1,02 & & & \\
\hline \multirow[t]{2}{*}{ Etkileşimsel Adalet } & Resmi okul & 535 & 3,61 & 1,13 & \multirow[t]{2}{*}{2,00} & \multirow[t]{2}{*}{787} & \multirow[t]{2}{*}{$0,046^{*}$} \\
\hline & Özel okul & 254 & 3,44 & 1,07 & & & \\
\hline \multirow[t]{2}{*}{ Örgütsel Adalet } & Resmi okul & 535 & 3,71 & 0,99 & \multirow[t]{2}{*}{1,72} & \multirow[t]{2}{*}{787} & \multirow[t]{2}{*}{0,086} \\
\hline & Özel okul & 254 & 3,58 & 0,97 & & & \\
\hline
\end{tabular}

$*_{p}<.05$

Öğretmenlerin, görev yaptıkları okul türünün örgütsel adalet algı düzeylerinde anlamlı bir farklılaşmaya neden olup olmadığını araştırmak üzere yapılan bağımsız/ilişkisiz gruplar ttestine göre okul türünün, sadece bir alt boyutta (etkileşimsel adalet) anlamlı bir farklılaşmaya neden olduğu görülmüştür (Tablo 12). Resmi ve özel okullarda görev yapan öğretmenlerin, etkileşimsel adalet algı düzeyleri arasında anlamlı bir fark olduğu ve bu farkın resmi okullarında görev yapan öğretmenler lehine olduğu bulunmuştur $\left[\mathrm{t}_{(787)}=2,00 ; \mathrm{p}<.05\right]$. Resmi okullarında görev yapan öğretmenlerin $\left(\bar{X}_{\text {Resmi }=3,61)}\right.$ çalıştıkları okullara ilişkin etkileşimsel adalet alg1 düzeyleri, özel okullarda görev yapan öğretmenlerden ( $\left.\bar{X}_{\text {Özel }}=3,44\right)$ daha yüksektir.

Tablo 13. Öğretmenlerin Örgütsel Adalet Algı Düzeylerinin Demografik Özelliklerine Göre Karşılaştırılmasına Yönelik Özet Tablo

\begin{tabular}{|c|c|c|c|c|}
\hline \multirow{2}{*}{ Değişkenler } & \multicolumn{4}{|c|}{ Örgütsel Adalet Ölçeği } \\
\hline & $\begin{array}{l}\text { Dağıtımsal } \\
\text { Adalet }\end{array}$ & $\begin{array}{c}\text { İşlemsel } \\
\text { Adalet }\end{array}$ & $\begin{array}{l}\text { Etkileşimsel } \\
\text { Adalet }\end{array}$ & $\begin{array}{c}\text { Örgütsel } \\
\text { Adalet }\end{array}$ \\
\hline Cinsiyet & $* * *$ & $* * *$ & $* * *$ & $* * *$ \\
\hline Yaş & * & & & \\
\hline Medeni durum & $*$ & $*$ & & \\
\hline Eğitim durumu & $* *$ & $* * *$ & $* * *$ & $* * *$ \\
\hline Branş & $*$ & & & \\
\hline Görev yapılan kademe & $* *$ & $*$ & $*$ & $* *$ \\
\hline Okul türü & & & * & \\
\hline \multicolumn{5}{|l|}{ Mesleki kıdem } \\
\hline \multicolumn{5}{|l|}{ Okuldaki çalışma süresi } \\
\hline${ }^{*} p<.05, * * p<.01, * * * p$ & & & & \\
\hline
\end{tabular}


farklılaşmaya neden olurken mesleki kıdem ve okuldaki çalışma süresi değişkenleri anlamlı bir farka neden olmamaktadır ( $\mathrm{p}>$.05).

Tablo 14. Öğretmenlerin Örgütsel Sinizm Düzeylerinin Yaşa Göre Karşılaştırılmasına Yönelik ANOVA testi $(\mathbf{N}=789)$

\begin{tabular}{|c|c|c|c|c|c|c|c|}
\hline \multirow{2}{*}{ Puan } & \multirow{2}{*}{ Yaş } & \multicolumn{3}{|c|}{ Betimsel İst. } & \multicolumn{2}{|c|}{ ANOVA } & \multirow{2}{*}{ Scheffe } \\
\hline & & $\mathrm{n}$ & $\bar{X}$ & SS & $\mathrm{F}$ & Sig. & \\
\hline \multirow[t]{4}{*}{ Bilişsel } & 30 ve altı (1) & 142 & 2,30 & 1,12 & 3,42 & $0,017 *$ & 4 ile 1,2 \\
\hline & $31-40(2)$ & 360 & 2,36 & 0,99 & & & \\
\hline & $41-50(3)$ & 209 & 2,17 & 0,98 & & & \\
\hline & 51 ve üstü (4) & 78 & 2,01 & 0,88 & & & \\
\hline \multirow[t]{4}{*}{ Duyuşsal } & 30 ve alt1 (1) & 142 & 1,79 & 1,06 & 0,75 & 0,524 & - \\
\hline & $31-40(2)$ & 360 & 1,84 & 1,09 & & & \\
\hline & $41-50(3)$ & 209 & 1,72 & 1,01 & & & \\
\hline & 51 ve üstü (4) & 78 & 1,70 & 1,05 & & & \\
\hline \multirow[t]{4}{*}{ Davranışsal } & 30 ve altı (1) & 142 & 2,41 & 1,05 & 5,02 & $0,002 * *$ & 1,2 ile 3,4 \\
\hline & $31-40(2)$ & 360 & 2,43 & 1,04 & & & \\
\hline & $41-50(3)$ & 209 & 2,22 & 0,99 & & & \\
\hline & 51 ve üstü (4) & 78 & 2,16 & 0,97 & & & \\
\hline \multirow[t]{4}{*}{ Örgütsel Sinizm } & 30 ve altı (1) & 142 & 2,20 & 0,94 & 3,34 & $0,019 *$ & 1,2 ile 3,4 \\
\hline & $31-40(2)$ & 360 & 2,21 & 0,90 & & & \\
\hline & $41-50(3)$ & 209 & 2,04 & 0,87 & & & \\
\hline & 51 ve üstü (4) & 78 & 1,92 & 0,85 & & & \\
\hline
\end{tabular}

Yapılan tek yönlü varyans analizine (one-way ANOVA) göre öğretmenlerin yaş1, ölçeğin iki boyutu (bilişsel ve davranışsal boyut) ve geneli bakımından anlamlı bir farklılaşmaya neden olmaktadır (Tablo 14).

Tablo 15. Öğretmenlerin Örgütsel Sinizm Düzeylerinin Cinsiyete Göre Karşılaştırılmasına Yönelik t-testi (N=789)

\begin{tabular}{|c|c|c|c|c|c|c|c|}
\hline \multirow{2}{*}{ Puan } & \multirow{2}{*}{ Cinsiyet } & \multicolumn{3}{|c|}{ Betimsel İst. } & \multicolumn{3}{|c|}{ t-test } \\
\hline & & $\mathrm{n}$ & $\bar{X}$ & ss & $\mathrm{t}$ & sd & $\mathrm{p}$ \\
\hline \multirow[t]{2}{*}{ Bilişsel } & Kadın & 583 & 2,32 & 1,02 & 3,00 & 787 & $0,003 * *$ \\
\hline & Erkek & 206 & 2,08 & 0,94 & & & \\
\hline \multirow[t]{2}{*}{ Duyuşsal } & Kadın & 583 & 1,85 & 1,08 & 2,59 & 787 & $0,010 *$ \\
\hline & Erkek & 206 & 1,62 & 0,99 & & & \\
\hline \multirow[t]{2}{*}{ Davranışsal } & Kadın & 583 & 2,43 & 1,06 & 3,55 & 787 & $0,000 * * *$ \\
\hline & Erkek & 206 & 2,13 & 0,92 & & & \\
\hline \multirow[t]{2}{*}{ Örgütsel Sinizm } & Kadın & 583 & 2,20 & 0,92 & 3,50 & 787 & $0,000 * * *$ \\
\hline & Erkek & 206 & 1,95 & 0,80 & & & \\
\hline
\end{tabular}

$* p<.05, * * p<.01, * * * p<.001$

Yapılan ilişkisiz gruplar t-testine göre cinsiyetin, öğretmenlerin hem genel hem de tüm alt boyutlarda sinizm düzeylerinde anlamlı bir farklılaşmaya neden olduğu görülmüştür (Tablo 15). Kadın öğretmenlerin, bilişsel, duyuşsal, davranışsal ve genel örgütsel sinizm 
düzeylerinin $\left(\bar{X}_{\text {Kadın}}=2,20\right)$ erkek öğretmenlerden $\left(\bar{X}_{\text {Erkek }=1,95)}\right.$ daha yüksek olduğu görülmüştür.

Tablo 16. Öğretmenlerin Örgütsel Sinizm Düzeylerinin Eğitim Duruma Göre Karşılaştırılmasına Yönelik Kruskal-Wallis testi (N=789)

\begin{tabular}{|c|c|c|c|c|c|c|c|}
\hline \multirow{2}{*}{ Puan } & \multirow{2}{*}{ Eğitim düzeyi } & \multicolumn{2}{|c|}{ Betimsel İst. } & \multicolumn{3}{|c|}{ Kruskal-Wallis } & \multirow{2}{*}{ M-W } \\
\hline & & $\mathrm{n}$ & Sira Ort. & $X^{2}$ & sd & $\mathrm{p}$ & \\
\hline \multirow[t]{3}{*}{ Bilişsel } & Ön Lisans (1) & 26 & 345,83 & 5,07 & 2 & $0,048 *$ & 1 ile 2,3 \\
\hline & Lisans (2) & 574 & 401,92 & & & & \\
\hline & YL/Doktora (3) & 189 & 409,26 & & & & \\
\hline \multirow[t]{3}{*}{ Duyuşsal } & Ön Lisans (1) & 26 & 391,06 & 3,07 & 2 & 0,216 & - \\
\hline & Lisans (2) & 574 & 387,37 & & & & \\
\hline & YL/Doktora (3) & 189 & 418,71 & & & & \\
\hline \multirow[t]{3}{*}{ Davranışsal } & Ön Lisans (1) & 26 & 303,63 & 8,59 & 2 & $0,014 *$ & 1 ile 2,3 \\
\hline & Lisans (2) & 574 & 405,41 & & & & \\
\hline & YL/Doktora (3) & 189 & 410,58 & & & & \\
\hline \multirow[t]{3}{*}{ Örgütsel Sinizm } & Ön Lisans (1) & 26 & 342,46 & 5,44 & 2 & $0,036^{*}$ & 1 ile 2,3 \\
\hline & Lisans (2) & 574 & 402,31 & & & & \\
\hline & YL/Doktora (3) & 189 & 410,58 & & & & \\
\hline
\end{tabular}

Yapılan non-parametrik Kruskal-Wallis testine göre öğretmenlerin eğitim durumu bilişsel, davranışsal alt boyutlarda ve genel örgütsel sinizm bakımından anlamlı bir farklılaşmaya neden olmaktadır. Tablo 16'da de görüldüğü üzere yüksek lisans/doktora mezunu öğretmenlerin örgütsel sinizm düzeyleri daha yüksektir.

Tablo 17. Öğretmenlerin Örgütsel Sinizm Düzeylerinin Görev Yaptıkları Okul Türüne Göre Karşılaştırılmasına Yönelik t- testi $(\mathbf{N}=789)$

\begin{tabular}{|c|c|c|c|c|c|c|c|}
\hline \multirow{2}{*}{ Puan } & \multirow{2}{*}{ Okul türü } & \multicolumn{3}{|c|}{ Betimsel İst. } & \multicolumn{3}{|c|}{ t-test } \\
\hline & & $\mathrm{n}$ & $\bar{X}$ & ss & $\mathrm{t}$ & $\mathrm{sd}$ & $\mathrm{p}$ \\
\hline \multirow[t]{2}{*}{ Bilişsel } & Resmi okul & 535 & 2,27 & 1,02 & 0,26 & 787 & 0,794 \\
\hline & Özel okul & 254 & 2,25 & 0,98 & & & \\
\hline \multirow[t]{2}{*}{ Duyuşsal } & Resmi okul & 535 & 1,81 & 1,09 & 0,81 & 787 & 0,418 \\
\hline & Özel okul & 254 & 1,74 & 0,99 & & & \\
\hline \multirow[t]{2}{*}{ Davranışsal } & Resmi okul & 535 & 2,41 & 1,04 & 2,40 & 787 & $0,017 *$ \\
\hline & Özel okul & 254 & 2,22 & 1,00 & & & \\
\hline \multirow[t]{2}{*}{ Örgütsel Sinizm } & Resmi okul & 535 & 2,16 & 0,92 & 1,33 & 787 & 0,184 \\
\hline & Özel okul & 254 & 2,07 & 0,85 & & & \\
\hline
\end{tabular}

$*_{p}<.05$

Öğretmenlerin, görev yaptıkları okul türünün örgütsel sinizm düzeylerinde anlamlı bir farklılaşmaya neden olup olmadığını araştırmak üzere yapılan bağımsız/ilişkisiz gruplar t-testine göre okul türü, ölçeğin sadece bir alt boyutu (davranışsal sinizm) bakımından anlamlı bir farklılaşmaya neden olmaktadır (Tablo 17). Resmi ve özel okullarda görev yapan öğretmenlerin, 
davranışsal boyut puanları arasında anlamlı bir fark olduğu bulunmuştur [ $\left.\mathrm{t}_{(796)}=2,40 ; \mathrm{p}<.05\right]$. Resmi okullarında görev yapan öğretmenlerinin $\left(\bar{X}_{\text {Resmi }}=2,41\right)$ davranışsal boyut puanları, özel

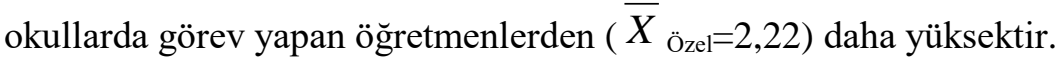

Tablo 18. Öğretmenlerin Örgütsel Sinizm Düzeylerinin Demografik Özelliklerine Göre Karşılaştırılmasına Yönelik Özet Tablo

\begin{tabular}{lcccc}
\hline & \multicolumn{4}{c}{ Örgütsel Sinizm Ölçeği } \\
\cline { 2 - 5 } Değişkenler & Bilişsel & Duyuşsal & Davranışsal & $\begin{array}{c}\text { Örgütsel } \\
\text { Sinizm }\end{array}$ \\
\hline Cinsiyet & $* *$ & $*$ & $* *$ & $* *$ \\
Yaş & $* *$ & & $* *$ & $* *$ \\
Medeni durum & & & $*$ & $*$ \\
Eğitim durumu & $*$ & & & $*$ \\
Branş & & $*$ & $*$ & $*$ \\
Görev yapıllan kademe & $* * u ̈ r u ̈$ \\
Mesleki kıdem & $*$ & & $* *$ & \\
Okuldaki çalışma süresi & & & &
\end{tabular}

Araştırmaya katılan öğretmenlerinin örgütsel sinizm düzeylerinin demografik özelliklerine göre farklılaşmalarını özetlemek gerekirse (Tablo 18); öğretmenlerin, cinsiyeti, yaş1, eğitim durumu, görev yapılan okul kademesi (ilkokul/ortaokul), görev yapılan okul türü ve mesleki kıdem anlamlı bir farklılaşmaya neden olurken medeni durum, branş ve okuldaki çalışma süresi değişkenleri anlamlı bir farka neden olmamaktadır ( $\mathrm{p}>.05)$.

\section{Nitel Araştırma Bulguları}

Örgütsel adalete ilişkin öğretmen algılarını ölçmeye yönelik sorulara öğretmenlerin yüz yüze yapılan görüşmelerde verdikleri yanıtlardan bir kısmı ve bu verilerin analizleri sonucunda oluşturulan temalar ve alt temalar (Tablo 19-22) aşağıda sunulmuştur.

"Adalet", "adil olmak" kavramı size ne ifade ediyor? Adil olan bir kişi hangi özellikleri taşır? Kişinin rengi, cinsiyeti, tercihleri ne olursa olsun verdiği hizmeti yansız bir şekilde sunmaktır. Adil olan kişi, uygulamalarda adil, eşitlikçi olmalı. Kişinin görüşü, siyasal bakış açısına göre karar vermemeli (ROE1).

Adil olan kişi herkese eşit davranır. Dil, din, ırk, sendikal vb. ayrımlar yapmaz (ROK1). Adalet, herkese eşit davranmak, hakkı olanı vermek demektir. Adil olan kişi hakkaniyetli davranmalı, davranışları tutarlı olmalı, yasa ve yönetmelikleri herkese eşit ve tarafs1z uygulanmalı (ROK2).

Çalıştığınız kurumda ödül, terfi, görev ve kaynak dağılımları sizce nasıl yapılıyor? Objektif kriterler var mı, adil ve eşit mi?

Herhangi bir kriter yok. Yerleşmiş bir ödül ve terfi sistemi yok. Genellikle yönetim kendi arkadaşlarına ödül ve terfide öncelik tanıyor (ROK2).

Objektif kriterler olmasa da "adil ve eşit" olduğunu düşünüyorum. Terfileri de kişinin alan bilgisi, yeterliliği de çok önemli oluyor. Alan hâkimiyeti, akademik yetkinliklere bak1larak görevlendirme yap1lıyor (ÖOK2-V).

Görev yaptığınız kurumda adil uygulamalar olmadığını algıladığınız zamanlar ne tür tepkiler veriyorsunuz? Bu durum sizi nasıl etkiliyor? 
Zaman zaman yöneticilerimin ben de yarattığı gerilimi sınıfın içine sokmuyorum. Sorun idare ile benim aramda kalıyor, sınıfıma, eğitim ortamına yansıtmıyorum. Bu durum motivasyonumu, yaratıcılığımı olumsuz etkiliyor (ROE1).

Adil uygulamalar, etik uygulamalar olmadığında üzülüyorum, motivasyonum düşüyor (ÖOE1).

Okulun işleyişi hakkında bilgi sahibi misiniz? Karar süreci nasıl işliyor, kararlar size nasıl bildiriliyor?

Bulunduğum okul eski bir okul ve yerleşik kuralları var. Kararlar sene baş1 toplantısında alınıyor. Okul müdürü bu konuda demokratik davranıyor (ROK1).

Karar süreçlerine katılmamız pek fazla olmuyor. Yönetim tarafından alınan kararlar bizlere bildiriliyor (ÖOE1).

Okulunuzda iş görenler arasındaki iletişim nasıldır ? Okul yöneticileri-öğretmen, öğretmenöğretmen?

Sendikal farklar, siyasi görüş açılarından kaynaklanan öğretmenler arası bir gerilim yaşanabiliyor. İnformal gruplaşmalar oluşabiliyor öğretmenler odasında sendikal farklar, siyasi görüş farklılıkları hatta eğitime bakış açılarından dolayı (ROE1).

Okul yöneticilerimiz çok sık değiştiği için istikrarlı bir yapı ve iletişim yok. Her sene farklı yöneticiler, farklı kurallar. Bu durum etkili bir iletişimi engelliyor (ÖOE2).

\section{Tablo 19. Tema 1- Adalet ve Adil Olmak}

\begin{tabular}{cl}
\hline \multicolumn{1}{c}{ Ana Tema } & \multicolumn{1}{c}{ Alt Temalar } \\
\hline & Renk, cinsiyet, mezhep vb. ayrım yapmamak \\
& Siyasal, sendikal fark gözetmemek \\
& Yansız, adil ve eşitlikçi uygulama \\
& Hak edene hakkını vermek \\
& Tarafsılık, tutarlılık \\
& Yasa ve yönetmelikleri eşit uygulama \\
Adalet ve Adil Olmak & Objektif kriterler \\
& Her görüşe saygı \\
& Doğruluk, haktan yana olmak \\
& Önyargısı davranmak \\
\hline
\end{tabular}

Öğretmenler, adalet ve adil olmak kavramını genel olarak “ yansız, adil, hakkaniyetli olmak, yasa-yönetmelikleri herkese eşit uygulamak ve siyasal-sendikal farklara göre ayrım yapmamak" olarak ifade etmişlerdir.

Tablo 20. Tema 2- Adil Olmayan Uygulamaların Öğretmenler Üzerindeki Etkileri

\begin{tabular}{ll}
\hline \multicolumn{1}{c}{ Ana Tema } & \multicolumn{1}{c}{ Alt Temalar } \\
\hline & Motivasyon düşmesi \\
& Yaratıcılığın azalması \\
& Mutsuz hissetme \\
& Moral bozukluğu \\
& Örgütsel sessizlik \\
Adil Olmayan Uygulamaların & Performansın düşmesi \\
Öğretmenler Üzerindeki Etkileri & Üzüntü, kızgınlık \\
& İletişism kopukluğu \\
& Çatışma \\
& Örgütsel adanmışlı̆̆ın azalması \\
& Sinik tutumlar geliştirme \\
\hline
\end{tabular}


Araştırmaya katılan öğretmenler okullarında adil uygulamalar olmadığında “ motivasyon ve performanslarının düştüğünü, yaratıcılıklarının ve örgütsel adanmışlıklarının azaldığını, moral bozukluğu yaşadıklarını, bireyler ve gruplar arası çatışmaların yaşandığını ve sinik tutumlar geliştirdiklerini” ifade etmişlerdir.

Tablo 21. Tema 3- Kararlara Katılım

\begin{tabular}{ll}
\hline \multicolumn{1}{c}{ Ana Tema } & \multicolumn{1}{c}{ Alt Temalar } \\
\hline & İnisiyatif \\
& Fikir, görüş \\
& Söz hakkı \\
Kararlara Katılım & Demokratik davranış \\
& Karar sürecine katııım \\
& Uygulanabilir kararlar \\
& Merkezi yönetim \\
& Karar merkezinin dişında olmak \\
\hline
\end{tabular}

Öğretmenler, karar alma süreçleriyle ilgili olarak gerek resmi gerekse özel okullarda “ genel olarak kararların alınış sürecinde demokratik bir karar süreci olmadığını, görüşlerinin alınmadığını ve kararların daha yönetim tarafından alındığını fakat kurumsal özel/vakıf okullarında kararlara katılım sürecinin kısmen daha demokratik işlediğini” ifade etmişlerdir.

Tablo 22. Tema 4- İletișim ve Etkileșim

\begin{tabular}{ll}
\hline \multicolumn{1}{c}{ Ana Tema } & \multicolumn{1}{c}{ Alt Temalar } \\
\hline & Açık iletişim \\
& Etkili iletşimim \\
& Sinılı iletşşim \\
& İnormal gruplar \\
İletişim ve Etkileşim & Siyasal görüş, sendikal farklar \\
& Otosansür \\
& Çatışma \\
& İletişim kopukluğu \\
\hline
\end{tabular}

Katılımcılar okul ortamındaki iletişimle ilgili olarak " genelde etkili ve açık bir iletişim olmadığını, özellikler resmi okullarda siyasal görüş ve sendikal farklılıklarına göre ayrışmalar olduğunu, bunun da hem çatışmalara neden olduğunu hem de açık ve etkili bir iletişimi engellediğini" ifade etmişlerdir.

\section{Tartışma ve Sonuç}

Öğretmenlerin algılarına göre örgütsel adalet ile örgütsel sinizm arasındaki ilişkiyi inceleyen bu araştırmada, öğretmenlerin örgütsel adalete ilişkin algı düzeyleri ile genel örgütsel sinizm düzeyleri arasında negatif yönde yüksek düzeyde anlamlı ilişki olduğu saptanmıştır. Öğretmenlerin, örgütsel adaletin alt boyutları olan dağıtımsal, işlemsel ve etkileşimsel adalete ilişkin algı düzeyleri ile; örgütsel sinizmin alt boyutları olan bilişsel sinizm, duyuşsal sinizm, davranışsal sinizm ve örgütsel sinizm arasında da negatif düzeyde ve güçlü derecede anlamlı bir ilişki olduğu saptanmıştır. Araştırmaya katılan öğretmenlerin hem genel örgütsel adalet algılarının hem de dağıtımsal, işlemsel ve etkileşimsel adalet alt boyutlarında adalet algılarının yüksek olduğu görülmüştür. Öğretmenlerin örgütsel adalet alg1 düzeyleri demografik özelliklerine göre ise şöyledir: Öğretmenlerin, cinsiyeti, yaşı, medeni durumu, eğitim durumu, branşı, görev yaptıkları okul kademesi ve görev yaptıkları okul türü anlamlı farklılaşmaya neden 
olurken mesleki kıdem ve okuldaki çalışma süresi değişkenlerinin anlamlı bir farka neden olmadığı görülmüştür. Bu durum-özellikle örgütsel sinizm ile örgütsel adalet arasındaki ilişki bağlamında-aşağıda verilen araştırma sonuçlarıyla da büyük ölçüde örtüşmektedir. Köybaşı , Uğurlu ve Öncel'in (2017) yaptıkları "Öğretmenlerin örgütsel adalet algıları ile örgütsel sinizm düzeyleri arasındaki ilişkinin incelenmesi” adlı araştırmada örgütsel sinizm ile örgütsel adalet arasında yüksek düzeyde ilişki olduğu saptanmıştır. Çetin, Özgan ve Bozbayındır'ın (2013) yaptıkları "İköğretim öğretmenlerinin örgütsel adalet ile sinizm algıları arasındaki ilişkinin incelenmesi" adlı araştırmada öğretmenlerin örgütsel adalet ile örgütsel sinizm algıları arasında anlaml1, negatif ve orta düzeyde bir ilişki olduğu sonucuna ulaşılmıştır. Bölükbaşığlu'nun (2013) "Öğretmenlerin örgütsel adalet algıları ile örgütsel sinizm tutumları arasındaki ilişki" adlı çalışmasında, öğretmenlerin örgütsel adalet algılarının cinsiyet değişkenine göre anlamlı bir farklılaşma göstermediği görülmüştür. Araştırmada incelenen branş, eğitim durumu, okul tipi, mezun olunan okul değişkenlerine ait sonuçlara bakıldığında da anlamlı bir farklılık bulunmamıştır. Örgütsel adalet algısı ve örgütsel sinizm düzeyi arasında negatif yönde bir ilişki olduğu sonucuna varılmıştır. Girgin ve Gümüşeli'nin yaptıkları (2018) "Meslek lisesi öğretmenlerinin örgütsel adalet ile örgütsel sinizm algıları arasındaki ilişkinin incelenmesi” adlı araştırmada, öğretmenlerin örgütsel adalet algıları ile örgütsel sinizm düzeyleri arasında negatif yönlü "yüksek" düzeyde anlamlı bir ilişki olduğu bulunmuştur. Öğretmenlerin örgütsel adalet algıları arttıkça örgütsel sinizm düzeyleri azalmaktadır. Kutanis ve Çetinel'in (2010) "Adaletsizlik algısı sinizmi tetikler mi? Bir örnek olay" adlı araştırma sonucunda sinik tutumlar sergileyen akademisyenlerin genel olarak örgütsel adalete ilişkin olumsuz algılara sahip oldukları sonucuna varılmıştır. Yine bu araştırmaya katılan öğretmenlerin hem genel örgütsel sinizm düzeyleri hem de örgütsel sinizmin bilişsel, duyuşsal ve davranışsal alt boyutlarında sinizm düzeylerinin düşük olduğu görülmüş̧ür. Bu araştırma sonuçlarına göre öğretmenlerinin örgütsel sinizm düzeylerinin demografik özelliklerine göre farklılaşmalarını özetlemek gerekirse: Öğretmenlerin, cinsiyeti, yaşı, eğitim durumu, görev yapılan okul kademesi , görev yapılan okul türü ve mesleki kıdem değişkenleri anlamlı farklılaşmaya neden olurken medeni durum, branş ve okuldaki çalışma süresi değişkenleri anlamlı bir farka neden olmamaktadır. Bu sonuçlar, cinsiyet ve branş değişkenleri dışında büyük ölçüde Kalağan ve Güzeller'in yaptıkları (2010) "Öğretmenlerin örgütsel sinizm düzeylerinin incelenmesi” adlı araştırma sonuçlarıyla da örtüşmektedir. Söz konusu çalışmada; öğretmenlerin örgütsel sinizm düzeyi ile branşları, mesleki kıdemleri, eğitim durumları, çalıştıkları okul türü, öğretmenliği seçme nedenleri arasındaki anlamlı bir ilişki bulunmuştur. Aynı araştırmanın bulguları öğretmenlerin cinsiyetleri ile örgütsel sinizm düzeyleri arasında anlamlı bir ilişki olmadığını göstermektedir.

$\mathrm{Bu}$ araştırmanın nitel kısmında öğretmenlerle yüz yüze yapılan görüşmelerde elde edilen bulgular 1şığında; gerek resmi gerekse özel okullarda görev yapan öğretmenlerin örgütsel adalet algılarının ve sinizm düzeylerinin farklılık gösterdiği görülmüştür. Elde edilen nitel bulgulara göre, öğretmenlerin genel olarak okullarında ödül, terfi, görev ve kaynak dağılımlarına ilişkin objektif kriterler olmadığından ve kararların alınmasında demokratik, katılımcı bir yaklaşım sergilenmediğinden yakındıkları görülmüştür.

Herhangi bir kriter yok. Yerleşmiş bir ödül ve terfi sistemi yok. Genellikle yönetim kendi arkadaşlarına ödül ve terfide öncelik tanıyor (ROK2). 
Ödül, terfi ve benzeri konularla ilgili süreçlere öğretmenler hiç dahil değil. Objektif kriterler olmadığını düşünüyorum. Bizi nasıl, neye göre değerlendirdikleri belirsiz (ÖOK5).

Karar süreçlerine katılmamız pek fazla olmuyor. Yönetim tarafından alınan kararlar bizlere bildiriliyor (ÖOE1).

Öğretmenlerin büyük bir kısmı, “Adalet ve adil olmak size neyi ifade ediyor?” sorusunu "yansız, adil, hakkaniyetli olmak, yasa-yönetmelikleri herkese eşit uygulamak ve siyasalsendikal farklara göre ayrım yapmamak" şeklinde yanıtlamışlardır.

Adalet ve adil olmak eğitim alanında kişinin rengi, cinsiyeti, tercihleri ne olursa olsun verdiği hizmeti yansız bir şekilde sunmaktır. Adil olan kişi, uygulamalarda adil, eşitlikçi olmalı. Kişinin görüşü, Siyasal bakış açısına göre karar vermemeli (ROE1).

Adil olan kişi herkese eşit davranır. Dil, din, ırk, sendikal ve benzeri ayrımlar yapmaz (ROK1).

Öğretmenler "Okullarındaki adil olmayan uygulamaların" üzerlerindeki etkilerini ise "motivasyon ve performanslarının düşmesi, yaratıcılıklarının ve örgütsel adanmışlıklarının azalması, moral bozukluğu, bireyler ve gruplar arası çatışmaların ortaya çıkması ve sinik davranışlar sergileme" şeklinde ifade etmişlerdir. Yine yüz yüze yapılan görüşmelerde elde edilen bulgulara göre örgütsel adalet algısının düşük olduğu durumlarda; öğretmenlerin sinik davranışlar sergiledikleri fakat bu sinik tutumlarını eğitim öğretim ortamına yansıtmadıklarını ifade etmişlerdir.

Zaman zaman yöneticilerimin ben de yarattığı gerilimi sınıfın içine sokmuyorum. Sorun idare ile benim aramda kalıyor, sınıfıma, eğitim ortamına yansıtmıyorum. Bu durum motivasyonumu, yaratıcılığımı olumsuz etkiliyor (ROE1).

Adil uygulamalar, etik uygulamalar olmadığında üzülüyorum, motivasyonum düşüyor (ÖOE1).

Sonuç olarak, bir karma yöntem araştırması olan fakat temelde nicel bir çalışma olan ve öğretmenlerin örgütsel adalete ilişkin alg1 düzeyleri ile örgütsel sinizm düzeyleri arasında negatif yönde yüksek düzeyde anlamlı bir ilişki olduğu ortaya koyan bu çalışmanın alan yazına katkı yapacağı umulmaktadır. Ayrıca, bu araştırmanın, kanun koyucular, eğitim liderleri ve özel okul kurucu ve yöneticilerinde örgütsel adalet ve örgütsel sinizm kavramları konularında farkındalık yaratacağ 1 ve bu konuyu daha kapsamlı inceleyecek olan araştırmacıları cesaretlendirerek bu araştırmanın bulguları ışığında onlara yol göstereceği umulmaktadır. 


\section{Kaynakça}

Andersson, L. M., \& Bateman, T. S. (1996). Cynicism in the work place: Some causes and effects. Journal of Organizational Behaviour, 18, 449-469.

Başaran, İ. E. (2004). Yönetimde insan ilişkileri: Yönetsel davranış. Nobel yayın dağıtım.

Brandes, P., \& Das, D. (2006). Locating behavioral cynicism at work: Construct issues and performance implications. In Employee health, coping and methodologies (pp. 233-266). Emerald Group Publishing

Büyüköztürk, Ş. (2007). Sosyal bilimler için veri analizi el kitabı (7. baskı). Ankara: Pegem.

Colquitt, J. A., Greenberg, J., \& Zapata-Phelan, C. P. (2005). What is organizational justice? A historical overview. In J. Greenberg \& J. A. Colquitt (Eds.), Handbook of organizational justice (pp. 3-56). Mahwah, NJ: Lawrence Erlbaum Associates.

Cropanzano, R., Ambrose, M. L., Greenberg, J., \& Cropanzano, R. (2001). Procedural and distributive justice are more similar than you think: A monistic perspective and a research agenda. Advances in organizational justice, 119, 151.

Çetin, B., Özgan, H., ve Bozbayındır, F. (2013). İlköğretim öğretmenlerinin örgütsel adalet ile sinizm algıları arasındaki ilişkinin incelenmesi. Akademik Bakış Dergisi, 37, 1-20.

Çırak, S., ve Baskan, G.A. (2015). İlköğretim okulu öğretmenlerinin örgütsel adalet algısı-Ankara-Yeni Mahalle. K. U. Kastamonu Eğitim Dergisi. 23 (3), 1091-1106

Dean, J. W., Brandes, P., \& Dharwadkar, R. (1998). Organizational cynicism. Academy of Management review, 23(2), 341-352.

Eaton, J. A. (2000). A social motivation approach to organizational cynicism. Unpublished Doctoral Dissertation, Graduate Program in Psychology, York University, Toronto.

Efeoğlu, İ. E., ve İplik, A. G. E. (2011). Algılanan örgütsel adaletin örgütsel sinizm üzerindeki etkilerini belirlemeye yönelik ilaç sektöründe bir uygulama. Çukurova Üniversitesi Sosyal Bilimler Enstitüsü Dergisi, 20(3), 343-360.

Folger, R., \& Cropanzano, R. (2001). Fairness theory: Justice as accountability. Advances in organizational justice, 1, 1-55.

Girgin, S., \& Gümüşeli, A. İ. (2018). A Study On The Correlation Between Organizational Justice And Organizational Cynicism Perceived By Vocational High School Teachers. European Journal of Education, 4(4), 446.

Greenberg, J. E., \& Colquitt, J. A. (2014). Handbook of organizational justice. London: Psy. Press

Greenberg, J. (1990). Organizational justice: Yesterday, today, and tomorrow. Journal of management, 16(2), 399-432.

Gümüşeli, A. İ. (1996). Okul müdürlerinin öğretim liderliğini sınırlayan etkenler. Kuram ve Uygulamada Eğitim Yönetimi, 6(6), 201.

Gün, F., ve Baskan, G.A. (2015). Öğretim elemanlarının algılarına göre örgütsel sinizm ile tükenmişlik düzeyleri arasındaki ilişkinin incelenmesi. Hacettepe Üniversitesi Eğitim Fakültesi Dergisi (H.U.Journal of Education). 32(2), 361-379.

Helvac1, M. A., (2010). Ö.Sinizm ve YY Yaklaşımlar. Ankara: Pegem Akademi

İçerli, L. (2010). Örgütsel Adalet: Kuramsal Bir Yaklaşım. Girişimcilik ve Kalkınma Dergisi, 5(1), 67-92.

Jöreskog, K. G., \& Sörbom, D. (1979). Advances in factor analysis and structural equation models. New York: University Press of America.

Kalağan, G. (2009). Araştırma görevlilerinin örgütsel destek algıları ile örgütsel sinizm tutumları arasındaki ilişki. Akdeniz Üniversitesi, Antalya.

Kalağan, G. ve Güzeller, C. O. (2010). Ögretmenlerin örgütsel sinizm düzeylerinin incelenmesi. Pamukkale Üniversitesi Egitim Fakültesi Dergisi, 27, 83-97.

Karagöz, Y. (2016). SPSS ve AMOS Uygulamalı İstatistiksel Analizler, Güncellenmiş 2. Basım, Nobel Yayınevi, Ankara.Karasar, N. (2006). Bilimsel Araştırma Yöntemi: Kavramlar-İlkeler-Teknikler (16. Basım) Nobel Yayın Dağıtım, Ankara. 
Köklü, N., ve Büyüköztürk, Ş. (2000). Sosyal bilimler için istatistiğe giriş. Ankara: Pegem Yayıncılık.

Kasalak, G. (2017). Ortaöğretim Kurumlarında Örgütsel Sinizm ve Örgütsel Adaletin Örgütsel Bağlllık Üzerindeki Etkisi. Uluslararası Eğitim Bilimleri Dergisi, 4(11), 853-879.

Köybaşı, F., Uğurlu, C. T., \& Öncel, A. (2017). Examining the relationship between teachers' organizational justice perceptions and organizational cynicism levels. İnönü University Journal of the Faculty of Education, 18, 1-14.

Kutanis, R. Ö., ve Çetinel, E. (2010). Adaletsizlik algısı sinisizmi tetikler mi?: Bir örnek olay. Dumlupınar Üniversitesi Sosyal Bilimler Dergisi,26, 1-10.

Kwak, Y. H., \& Anbari, F. T. (2006). Benefits, obstacles, and future of six sigma approach. Technovation, 26(5-6), 708-715.

Leech, N.L. (2005). SPSS for Intermediate Statistics: Use and Interpretation. London: Lawrance Erlbaum Associates Publishers.

Mirvis, P. H., \& Kanter, D. L. (1989). Combatting cynicism in the workplace. Global Business and Organizational Excellence, 8(4), 377-394.

Mishra, A. K., \& Spreitzer, G. M. (1998). Explaining how survivors respond to downsizing: The roles of trust, empowerment, justice, and work redesign. Academy of management Review, 23(3), 567588.

Moorman, R. H. (1991). Relationship between organizational justice and organizational citizenship behaviors: Do fairness perceptions influence employee citizenship?. Journal of applied psychology, 76(6), 845 .

Naus, A.J.A.M. (2007). Organizational cynicism on the nature, antecedents, and consequences of employee cynicism toward the employing organization. Yayımlanmamış Doktora Tezi. Maastricht University, Maastricht

Özgan, H., Külekçi, E., ve Özkan, M. (2012). Öğretim elemanlarının örgütsel sinizm ile örgütsel bağl1lık düzeyleri arasındaki ilişkinin incelenmesi. International Online Journal of Educational Sciences, 4(1), 196-205.

Polat, S. (2007). Ortaöğretim Öğretmenlerinin Örgütsel Adalet Algıları, Örgütsel Güven Düzeyleri ile Örgütsel Vatandaşlık Davranışları Arasındaki İlişki. Yayınlanmış Doktora Tezi. Kocaeli Üniv.

Ribbers, I. L. (2009). Trust, cynicism, and organizational change: The role of management. Yayınlanmmaış Yüksek Lisans Tezi, University of Tilburg Department Organisation and Strategy, Tilburg, Netherlands.

Serinkan, C., ve Erdiş, Y.(2014). Dönüşümcü liderlik bağlamında örgütsel vatandaşlı ve örgütsel adalet. Ankara: Nobel Yayınevi.

Tutar, H. (2016). Örgütsel davranış. Ankara: Detay Yayıncılık. 


\section{Extended Abstract}

\section{Introduction}

The concepts of organizational justice and organizational cynicism have become important issues that have been frequently studied in educational organizations as well as in all other organizations in recent years since they affect organizational commitment, organizational citizenship, organizational trust, and organizational productivity. Organizational justice has become more important as the globalizing new world order increases the destructive effects of organizational cynicism due to the injustices and frustrations the employees think they suffer. According to Gerald (2002), when employees perceive prejudice and injustice in organizational decisions and administrative activities, they can feel negative emotions such as anger, resentment, and anger against the organization and management and develop cynical attitudes. Anderson (1996) stated that developing cynical attitudes is a reaction to help employees cope with their perceptions about the insufficient organizational output that they get in repayment of their labour and their judgement that the administrative and interaction processes used to determine these outputs are unfair. The aim of this study is to examine the relationship between organizational justice and organizational cynicism according to the perceptions of teachers working in public and private elementary and secondary schools.

\section{Methodology}

Although this study is planned as a mixed method research (quantitative and qualitative), it is basically a quantitative study of the relational screening model in descriptive nature. The universe of this research is composed of 31,167 teachers working in public and private elementary and secondary schools in 14 provinces on the Anatolian side of Istanbul, in the academic year of 2017-2018. A total of 789 teachers constitute the quantitative sample group of this study and a total of 20 public and private school teachers, who were interviewed face to face, constitute the qualitative sample group of this study. The data of the study was collected with the following scales and forms: "the personal information form", "organizational justice scale" developed by Niehoff and Moorman (1993) and adapted to Turkish by Polat (2007), "organizational cynicism scale" developed by Brandes, Dharwadkar and Dean (1999) and adapted to Turkish by Kalağan (2009) and a "face-to-face interview form" of 12 questions developed by the researcher. Statistical analyzes were done using SPSS 23.0 for Windows. In the analysis of the data, arithmetic mean, correlation coefficient, linear regression analysis, oneway variance analysis, One-way ANOVA, post-hoc Scheffe test, Kruskal-Wallis test and posthoc Mann-Whitney U test were used. The basic level of significance was accepted as 0.05 in all the statistical calculations made. Face to face interviews recorded with the permission of the interviewers was analyzed using descriptive and content analysis methods.

\section{Results and Discussion}

As a result of the research, it was determined that there was a significant and very strong relationship between teachers' organizational justice perception levels and organizational cynicism levels. In other words, as teachers' perceptions of organizational justice increased (positively), cynicism levels (general and cognitive, affective, behavioral dimensions) decreased (or vice versa). It has been observed that teachers' attitudes towards justice are high in both general organizational justice perceptions and distribution, procedural and interactional justice 
sub-dimensions. The teachers' gender, age, marital status, education status, branch, school level (primary/secondary) and school type (public/private) caused a meaningful difference in the level of organizational justice perception, but occupational seniority and duration of working in the school did not cause any significant difference. Both the organizational and the sub-dimensions (cognitive, affective, behavioral) cynicism levels of the teachers participating in the research were found to be low. The teachers' gender, age, education status, school level (primary schoolmiddle school), school type (official-private) and occupational seniority caused a meaningful difference in the level of organizational cynicism perception. Marital status, branch and duration of working in the school did not cause any significant difference. According to the findings obtained from qualitative data, through face-to-face interviews, it was revealed that the teachers have complained that there are no objective criteria for rewards, promotion, duties and resource distribution in their schools in general and that they did not have sufficient participation in the decision-making process and that a democratic, participatory approach was not taken in taking decisions. Again, according to the findings obtained from face-to-face interviews, when the teachers' perception of organizational justice is low, teachers showed cynic behaviors in cognitive, affective and behavioral dimensions, but they did not reflect these cynical attitudes in the educational environment. The results of this study, which revealed that there was a negative and significant relationship between teachers' perceptions of organizational justice and organizational cynicism attitudes, was largely consistent with the results of the following studies. Investigation of Teachers' Organizational Cynicism Levels (Kalağan \& Güzeller, 2010). In this study; A significant relationship was found between the teachers' organizational cynicism level and their branches, their seniority, their educational status, the type of school they worked and the reasons for choosing to be teachers. The findings of the same study showed that there was no significant relationship between teachers' gender and levels of organizational cynicism. Investigation of the Relationship between Organizational Justice and Organizational Cynicism according to the perceptions of Vocational High School Teachers (Girgin \& Gümüşeli, 2018).

According to the findings of this study, It was found that there was a significant negative correlation between organizational justice perceptions and organizational cynicism levels of teachers. The level of organizational cynicism decreases as teachers' perception of organizational justice increases.

In conclusion, this research revealed the relationship between organizational justice and organizational cynicism according to the perceptions of the teachers and the results were discussed in detail and contributed to the literature. 